\title{
Efektivitas pelatihan kerja terhadap kinerja kader Posyandu
}

\author{
Ni Made Darmiyanti, ${ }^{1}$ Ni Wayan Ari Adiputri ${ }^{2 *}$ \\ ${ }^{1,2}$ Politeknik Kesehatan Kartini Bali, Denpasar - Indonesia
}

\begin{abstract}
The number of Posyandu throughout Indonesia reaches 202,676 Posyandu, in Bali 4,791 Posyandu and Karangasem Regency 555 Posyandu, while in Manggis Village, there are 12 Posyandu. The level of utilization of Posyandu nationally in 2010 only reached 50.5\%, where there was a $12 \%$ decrease in the utilization of Posyandu until 2015. This should be in past tense the effectiveness of job training on Posyandu cadre's performance in Manggis Village, Manggis District, Karangasem Regency in 2018. The study was conducted with a quasi-experiment research design with the design pre-test post-test method. The research subjects used 60 Posyandu cadre in the Manggis Village area. The analysis used the Wilxocon Sign Rank Test with a confidence level of 0.05. The results showed that the value of $p=$ $0.00<0.05$, so that the job training given to Posyandu cadre had a significant effect on improving Posyandu cadre's performance.
\end{abstract}

Keywords: job training; cadre; performance

Jumlah Posyandu di seluruh Indonesia mencapai 202.676 Posyandu, di Bali 4.791 Posyandu dan di Kabupaten Karangasem 555 Posyandu, sedangkan untuk di Desa Manggis posyandu berjumlah 12 buah. Tingkat pemanfaatan Posyandu secara nasional pada tahun 2010 hanya mencapai 50,5\%, dimana terjadi penurunan sebesar $12 \%$ terhadap pemanfaatan Posyandu hingga rentang 2015. Penelitian ini bertujuan untuk mengetahui efektifitas pelatihan kerja terhadap kinerja kader posyandu di Desa Manggis, Kecamatan Manggis, Kabupaten Karangasem tahun 2018. Penelitian dilakukan dengan rancangan quasi experiment research dengan metode pre test post test design. Subjek penelitian menggunakan 60 kader posyandu yang berada di wilayah Desa Manggis. Analisis yang digunakan Wilxocon Sign Rank Test dengan tingkat kepercayaan 0,05. Hasil penelitian menunjukkan bahwa nilai $p=0,00<0,05$, sehingga pelatihan kerja yang diberikan kepada kader posyandu mempunyai efektifitas yang significan terhadap peningkatan kinerja kader Posyandu.

Kata Kunci: pelatihan kerja; kader; kinerja 


\section{Pendahuluan}

Posyandu adalah sistem pelayanan yang dipadukan antara satu program dengan program kesehatan lainnya. Posyandu merupakan bentuk peran serta masyarakat di bidang kesehatan, yang dikelola oleh kader, sasarannya adalah seluruh masyarakat (Kementerian Kesehatan RI., 2018)

Kualitas pelayanan posyandu dipengaruhi oleh keaktifan kader dan lokasi keberadaan posyandu (Husniyawati \& Wulandari, 2016). Selain keaktifan kader dan lokasi keberadaan posyandu, kelengkapan peralatan, cara kader dalam melayani peserta posyandu dan ketepatan waktu pelaksanaan dengan jadwal pelaksanaan merupakan faktor lain yang menjadi penentu dalam kualitas pelayanan posyandu (Putra, 2015).

Tingkat pemanfaatan posyandu secara nasional pada tahun 2014 hanya mencapai $60,5 \%$, dimana terjadi penurunan sebesar $12 \%$ terhadap pemanfatan posyandu hingga rentang 2017. Data Riskesdas menunjukkan 50\% balita di Indonesia tidak melakukan penimbangan teratur ke posyandu (Kementerian Kesehatan RI., 2018)

Pelatihan adalah suatu usaha peningkatan pengetahuan dan keahlian seseorang untuk mengerjakan suatu pekerjaan tertentu, Sinambela berpendapat bahwa pelatihan merupakan proses yang sistematis mengubah tingkah laku pegawai untuk mencapai tujuan organisasi yang berkatitan dengan keahlian dan kemampuan pegawai untuk melaksanakan pekerjaan saat (Sinambela, 2017).

Dalam rangka meningkatkan pemanfaatan posyandu oleh masyarakat, pemerintah sudah mencanangkan kembali untuk melakukan revitalisasi posyandu dengan memberi penyegaran/ pelatihan kembali, khususnya untuk kader yang baru (Herlangga et al., 2015). Berdasarkan uraian di atas, pelatihan kerja merupakan salah satu langkah untuk meningkatkan kinerja kader sehingga pemanfaatan posyandu dapat terlaksana optimal bagi masyarakat.

Penelitian Zaki, dkk tentang peningkatan kapasitas kader posyandu melalui pelatihan pemantauan status gizi balita menyatakan bahwa terjadi peningkatan pengetahuan dan kemampuan kader balita terutama dalam pengukuran berat badan bayi yang di atas dua tahun dan di bawah dua tahun, kemudian pengukuran tinggi badan balita dan menuliskan di dalam buku KMS (Zaki et al., 2018).

Hayati, dkk juga dalam penelitiannya tentang Pelatihan Kader Posyandu dalam Deeteksi Perkembangan Anak Usia Dini memperlihatkan bahwa kegiatan ini mampu memberikan beberapa alternatif penyelesaian masalah yang terjadi ketika kegiatan Posyandu berlangsung di wilayah Kecamatan Pleret Bantul seperti kesalahan dalam melakukan penimbangan berat badan dan pengukuran tinggi badan (Hayati et al., 2015).

Jumlah kader posyandu di Desa Manggis adalah 60 orang, namun yang aktif tidak lebih dari 50\%. Partisipasi masyarakat dalam memanfaatkan posyandu dapat dilihat dari pencapaian D/S Desa Manggis sebesar 63,3\% (target pencapaian $80 \%$ ). Cakupan posyandu ini dapat dipengaruhi oleh kinerja kader posyandu setempat. Kegiatan di meja penyuluhan pun tidak pernah dilakukan, karena kader tidak 
percaya diri dalam memberikan penyuluhan gizi dan kesehatan. Anggota kader posyandu sebagian besar merupakan anggota baru yang belum pernah mendapatkan pelatihan tentang penyelenggaraan kegiatan posyandu sehingga pengetahuan akan kegiatan posyandu pun masih berkurang. Berdasarkan permasalahan tersebut terlihat bahwa pelatihan kerja sangat diperlukan dalam membantu untuk meningkatkan kinerja kader posyandu.

\section{Metode}

Desain penelitian ini adalah eksperimen semu (quasi experiment design) dengan rancangan pre test post test design. Penelitian ini dilaksanakan di 12 Posyandu di Desa Manggis, Kecamatan Manggis Kabupaten Karangasem. Sampel dalam penelitian ini adalah seluruh ibu kader yang berjumlah 60 orang dengan mengambil total populasi. Data dikumpulkan dengan metode observasi langsung dengan menggunakan lembar observasi dan lembar kuesioner. Data dianalisis secara deskriptif dan bivariate dengan uji Wilcoxon Signed Rank Test yang merupakan uji statistic non parametric. Penelitian ini telah dinyatakan laik etik oleh Komisi Etik Penelitian Fakultas Kedokteran Universitas Udayana/ Rumah Sakit Umum Pusat Sanglah Denpasar dengan nomor surat 2931/UN14.2.2.VII.14/ LP/2018.

\section{Hasil dan Pembahasan}

Berdasarkan hasil penelitian ini menunjukkan bahwa pelatihan kerja efektif dalam meningkatkan kinerja kader posyandu. Program pelatihan kerja bertujuan untuk meningkatkan dan me- ngembangkan keterampilan, keahlian dan kecakapan serta kemampuan seorang karyawan (Sinambela, 2017). Pelatihan kerja juga merupakan sebuah proses pendidikan jangka pendek yang menggunakan prosedur sistematik dan terorganisasi dan menghasilkan kinerja yang lebih baik dan merupakan salah satu factor utama yang mempengaruhi kinerja kader posyandu (Yanti et al., 2016).

Gibson dalam Notoatmodjo mengemukakan bahwa faktor-faktor yang menentukan kinerja seseorang dikelompokkan menjadi tiga variabel utama, yakni: 1) Variabel individu yang terdiri dari pemahaman terhadap pekerjaan, pengalaman kerja, latar belakang keluarga, tingkat social ekonomi dan faktor demografi; 2) Variabel organisasi yang terdiri kepemimpinan, desain pekerjaan, struktur organisasi; 3) Variabel psikologis yang terdiri dari persepsi terhadap pekerjaan, sikap terhadap pekerjaan, motivasi, kepribadian (Notoatmodjo, 2015).

Hasil penelitian ini sesuai dengan penelitian yang dilakukan oleh Rudahliawan, dkk, tentang pengaruh pelatihan terhadap kemampun kerja dan kinerja karyawan dengan hasil bahwa pelatihan berpengaruh signifikan terhadap kinerja karyawan (Rudhaliawan \& Mahmudhitya, 2015). Hal ini juga sejalan dengan penelitian yang dilakukan oleh Oktaviani yang menyatakan bahwa pelatihan berpengaruh signifikan terhadap kinerja karyawan (Oktaviani \& Darmo, 2017). Purnomo dalam penelitian serupa juga mendapatkan hasil bahwa kemampuan pengelolaan posyandu setelah dilakukan pelatihan kader, hampir seluruhnya mendapat katagori baik (Purnomo, 2015). 
Tabel 1. Distribusi Frekuensi Karakteristik Kader Posyandu di Desa Manggis Kecamatan Manggis Tahun 2018

\begin{tabular}{|c|c|c|}
\hline Karakteristik & $\mathrm{n}$ & $\%$ \\
\hline \multicolumn{3}{|l|}{ Jenis Kelamin } \\
\hline Laki-laki & 12 & 20 \\
\hline Perempuan & 48 & 80 \\
\hline \multicolumn{3}{|l|}{ Usia } \\
\hline$<20$ tahun & 8 & 13,3 \\
\hline 21-49 tahun & 16 & 26,6 \\
\hline 50-59 tahun & 21 & 35 \\
\hline$>60$ tahun & 15 & 25 \\
\hline \multicolumn{3}{|l|}{ Pengalaman sebagai Kader } \\
\hline 3-12 bulan & 27 & 45 \\
\hline 1-5 tahun & 18 & 30 \\
\hline$>5$ tahun & 15 & 25 \\
\hline \multicolumn{3}{|l|}{ Pekerjaan } \\
\hline Bekerja & 17 & 28,3 \\
\hline Tidak Bekerja & 43 & 71,7 \\
\hline
\end{tabular}

Tabel 2. Distribusi Frekuensi Karakteristik Kinerja Kader Posyandu sebelum dan setelah Diberikan Pelatihan Kerja di Desa Manggis Kecamatan Manggis Tahun 2018

\begin{tabular}{|c|c|c|c|c|c|}
\hline \multirow{2}{*}{ No } & \multirow{2}{*}{ Kategori Kinerja } & \multicolumn{2}{|c|}{ Sebelum Diberikan Pelatihan Kerja } & \multicolumn{2}{|c|}{ Setelah Diberikan Pelatihan Kerja } \\
\hline & & $\mathrm{F}$ & $\%$ & $\mathrm{~F}$ & $\%$ \\
\hline 1. & Baik & - & - & 50 & 83,3 \\
\hline 2. & Cukup & 20 & 33,3 & 10 & 16,7 \\
\hline \multirow[t]{2}{*}{3.} & Kurang & 40 & 66,4 & - & - \\
\hline & Total & 60 & 100 & 60 & 100 \\
\hline
\end{tabular}

Tabel 3. Analisa Bivariate Kinerja Kader Posyandu sebelum dan setelah Diberikan Pelatihan Kerja di Desa Manggis Kecamatan Manggis Tahun 2018

\begin{tabular}{lllll}
\hline \multirow{2}{*}{ Variabel } & Mean & $\mathrm{P}$ & \multicolumn{2}{c}{$95 \% \mathrm{Cl}$} \\
\cline { 4 - 5 } & & & Batas Bawah & Batas Atas \\
\hline Tingkat Kinerja & 7,41 & 0,00 & 7,86 & 6,97 \\
\hline
\end{tabular}

Pelatihan bagi kader sangat penting untuk diberikan, dengan pelatihan diharapkan kader akan bekerja lebih efektif serta lebih maksimal sesuai dengan tanggung jawabnya. Pentingnya untuk melakukan pelatihan kader sangat dirasakan oleh kader itu sendiri, karena pada saat waktu berjalan muncul juga beberapa kader baru yang belum mendapat pelatihan kader sebelumnya, dan hal ini bisa menghambat kinerja kader (Tristanti \& Khoirunnisa, 2018).

Pelatihan yang diberikan kepada kader sedikit berbeda dengan pelatihan-pelatihan yang diberikan kepada karyawan suatu perusahan. Perbedaan ini disebabkan karena latarbelakang pen- 
didikan yang tidak berpendidikan tinggi, karena usia yang beragam, serta pengalaman yang juga beragam. Sehingga pelatihan kepada kader hendaknya diberikan dalam waktu yang tidak terlalu lama, tetapi sebaiknya disusun modul yang berisi bermain peran dan lain-lain supaya lebih menarik (Suyatno \& Kartasurya, 2019). Pelatihan yang berkali-kali pun juga tidak memberikan manfaat jika tidak terfokus pada kekurangan pengetahuan kader dalam pelaksanaan posyandu (Hardiyanti et al., 2018). Jenis-jenis pelatihan kader pun bisa seperti pelatihan gizi, pelatihan imunisasi, KB, kesehatan lingkungan, keorganisasian, kesehatan, lansia, dan PHBS (Taek et al., 2018).

Peningkatan kinerja kader posyandu ini juga dipengaruhi oleh sebagian besar subyek penelitian bekerja sebagai ibu rumah tangga (tidak bekerja) sehingga menjadi kader adalah kegiatan pengisi waktu luang, sehingga pada saat pelatihan kader bisa hadir dan bisa fokus dalam mengikuti pelatihan (Sulistyorini, 2015).

Kinerja kader posyandu memberikan implikasi yang sangat penting kepada kesehatan, khususnya kesehatan bayi dan balita (Sengkey et al., 2015). Posyandu diharapkan menjadi garda terdepan dalam penjaringan kesehatan bayi dan balita khususnya tentang status gizinya dan ini merupakan salah satu bentuk komitmen dari kader (Hidayat et al., 2018). Jika posyandu berjalan maksimal maka kasus gizi buruk bisa diminimalisir, karena status gizi kurang sudah terdeteksi lebih awal saat posyandu (Hayati et al., 2015). Dengan pelatihan kader mampu meningkatkan cakupan program kesehatan ibu dan anak (Nur et al., 2018).
Peningkatan kinerja kader setelah diberikan pelatihan juga dipengaruhi oleh post test atau penilaian kembali kinerja kader. Setelah diberikan pelatihan harus dilakukan segera post test tersebut pada posyandu bulan berikutnya, sehingga ingatan kader akan materi pelatihan yang diberikan masih segar dan hasilnya pun sangat baik. Pelatihan kader juga menjadi efektif setelah diberikan praktek kepada semua kader tentang pelaksanaan posyandu (Baswara Putra \& Denny Yuliatni, 2016). Pelatihan kader ini pun mampu meningkatkan kemampuan berkomunikasi kader dengan masyakarat (Retasari \& Anisa, 2018).

\section{Kesimpulan}

Dari hasil pengumpulan data sebelum diberikan pelatihan, data yang paling rendah adalah tentang 1). Apakah dilakukan penilaian kenaikan berat badan, 2). Apakah dilakukan pengukuran LiLa, dan apakah dilakukan kunjungan rumah. Dari 60 orang subyek penelitian tidak ada satu pun yang melakukan kegiatan tersebut. Sedangkan data yang persentasenya tinggi (100\%) adalah tentang 10> balita dilakukan pendaftaran dan 2). Hasil penimbangan dicatat di KMS.

Setelah dilakukan pelatihan kerja posyandu, data post test meningkat yang sebelumnya ada nilai $0 \%$ sekarang nilai minimal $73,3 \%$ atau dalam kategori cukup.

Secara garis besar kinerja kader posyandu sebelum diberikan pelatihan kerja menunjukkan sebagian besar $(66,4 \%)$ mempunyai kinerja dalam kategori kurang. Kinerja kader posyandu setelah diberikan pelatihan kerja menunjukkan bahwa sebagian besar $(83,3 \%)$ dalam kategori 
baik. Efektivitas pelatihan kerja terhadap kinerja kader posyandu setelah diberikan pelatihan kerja menunjukkan pengaruh yang signifikan terhadap peningkatan kinerja kader posyandu dengan nilai $p<0,05$.[]

\section{Daftar Pustaka}

Baswara Putra, G., \& Denny Yuliatni, P. (2016). Gambaran pengetahuan dan kinerja kader Posyandu di wilayah kerja UPT Puskesmas Mengwi I Kabupaten Badung pada bulan Juli Agustus 2015. E-Jurnal Medika Udayana, 5(10), 1-9.

Hardiyanti, R., Jus'at, I., \& Angkasa, D. (2018). Hubungan lama kerja menjadi kader, pengetahuan, pendidikan, pelatihan dengan presisi dan akurasi hasil penimbangan berat badan balita oleh kader Posyandu. AcTion: Aceh Nutrition Journal, 3(1), 74. https://doi.org/10.30867/action.v3i1.102

Hayati, N., Muthmainnah, M., \& Fatimaningrum, A. S. (2015). Pelatihan kader Posyandu dalam deteksi perkembangan anak usia dini. Jurnal Pendidikan Anak, 4(2), 651-658. https://doi.org/10.21831/jpa.v4i2.12359

Herlangga, J., Samino, \& Yanti, D. E. (2015). Faktorfaktor yang berhubungan dengan kinerja kader Posyandu di wilayah kerja Puskesmas Brabasan Kabupaten Mesuji. Jurnal Dunia Kesmas, 3(2), 84-90.

Hidayat, E. M., Ambarwati, R., \& Indriatie. (2018). The role of Posyandu cadres in improving the growth and development of toddlers in RW VII Puskesmas Mojo, Surabaya. Indian Journal of Public Health Research \& Development, 9(11), 1813-1817. https://doi.org/10.5958/ 0976-5506.2018.01709.6
Husniyawati, Y. R., \& Wulandari, R. D. (2016). Analisis motivasi terhadap kinerja kader Posyandu berdasarkan teori Victor Vroom. Jurnal Administrasi Kesehatan Indonesia, 4(2), 126135. https://doi.org/10.20473/jaki.v4i2.2016. 126-135

Kementerian Kesehatan RI. (2018). Profil Kesehatan Indonesia 2018. Pusdatin.Kemkes.Go.ld. https://pusdatin.kemkes.go.id/resources/do wnload/pusdatin/profil-kesehatanindonesia/PROFIL_KESEHATAN_2018_1.pdf

Notoatmodjo, S. (2015). Ilmu Prilaku Kesehatan. Rineka Cipta.

Nur, D. R. N., Husodo, B. T., \& Nugraha-P, P. (2018). factors related to the evaluation of the toddlers' growth early detection program at Taman Posyandu in Puskesmas Lamongan. Jumantik: Jurnal Mahasiswa dan Peneliti Kesehatan, 5(2). https://doi.org/10.29406/ jjum.v5i2.1275

Oktaviani, E., \& Darmo, I. S. (2017). Pengaruh pelatihan dan motivasi kerja terhadap kinerja pegawai Sekretariat Direktorat Jenderal Pengelolaan Pembiayaan dan Risiko Ke menterian Keuangan. Jurnal Riset Manaje men dan Bisnis (JRMB), 2(3), 373-380. https://doi.org/10.36226/jrmb.v2i3.71

Purnomo, G. A. (2015). Pengaruh pelatihan kader tentang Posyandu terhadap lemampuan pengelolaan Posyandu di Desa Sendangsari Kecamatan Pengasih Kulon Progo [STIKES 'Aisyiyah Yogyakarta]. http://digilib. unisayogya.ac.id/337/

Putra, D. (2015). Faktor yang berhubungan dengan pemanfaatan posyandu lansia di wilayah kerja Puskesmas Sikapak Kota Pariaman tahun 2015. Universitas Andalas.

Retasari, D., \& Anisa, R. (2018). Communication for cadres at Posyandu Kuntum Mekar (the phenomenology study about the meaning of 
communication for cadres at Posyandu Kuntum Mekar in Jaya Mekar Village, Subdistrict Padalarang, West Bandung District). The 1st Proceedings of The International Conference on Social Sciences (ICSS), 78-84.

Rudhaliawan, \& Mahmudhitya, V. (2015). Pengaruh pelatihan terhadap kemampuan kerja dan kinerja karyawan (Studi pada karyawan PT. Telkom Indonesia, Tbk Kandatel Malang). Jurnal Administrasi Bisnis, 4(2).

Sengkey, S. W., Kandou, G. D., \& Pangemanan, J. M. (2015). Analisis Kinerja Kader Posyandu di Puskesmas Paniki Kota Manado. JIKMU Jurnal IImu Kesehatan Masyarakat Unsrat, 5(5), 491-501.

Sinambela, L. P. (2017). Manajemen Sumber Daya Manusia. Bumi Aksara.

Sulistyorini, L. (2015). Pengaruh pelatihan kader Posyandu terhadap motivasi dan keaktifan sebagai Prokes (Promotor Kesehatan Desa) dalam pencegah penyakit dipteri pada anak balita di Desa Karangharjo Kecamatan Silo Kabupaten Jember [Universitas Jember]. http://ura.unej.ac.id/123456789/68528

Suyatno, \& Kartasurya, M. I. (2019). The effectiveness of training and mentoring activities to improve cadre performance in child growth monitoring (CGM). Indian Journal of Public
Health Research and Development, 10(3), 1032-1038. https://doi.org/10.5958/09765506.2019.00639.9

Taek, J. D., Tnomel, K., \& Oeleu, S. (2018). Effect performance of Posyandu toddlers cadre against satisfaction level mother of toddlers at Posyandu Melati 9 Health Center Liliba Kota Kupang. Journal of Nursing Practice, 1(2), 33-40. https://doi.org/10.30994/ jnp.v1i2.31

Tristanti, I., \& Khoirunnisa, F. N. (2018). Kinerja kader kesehatan dalam pelaksanaan Posyandu di Kabupaten Kudus. Jurnal Ilmu Keperawatan dan Kebidanan, 9(2), 192-199. https:// doi.org/10.26751/jikk.v9i2.470

Yanti, S. V., Hasballah, K., \& Mulyadi, M. (2016). Studi Komparatif Kinerja Kader Posyandu. Jurnal Keperawatan, 4(2), 1-11.

Zaki, I., Farida, F., \& Sari, H. P. (2018). Peningkatan kapasitas kader Posyandu melalui pelatihan pemantauan status gizi balita. Jurnal Pengabdian Kepada Masyarakat, 3(2), 169-177. https://doi.org/10.22146/jpkm.28595 
This page itentionally left blank. 